\title{
The effect of moisture addition with a mold inhibitor on feed manufacture, pellet quality, and broiler performance
}

John M. Hott

West Virginia University

Follow this and additional works at: https://researchrepository.wvu.edu/etd

\section{Recommended Citation}

Hott, John M., "The effect of moisture addition with a mold inhibitor on feed manufacture, pellet quality, and broiler performance" (2007). Graduate Theses, Dissertations, and Problem Reports. 2535.

https://researchrepository.wvu.edu/etd/2535

This Thesis is protected by copyright and/or related rights. It has been brought to you by the The Research Repository @ WVU with permission from the rights-holder(s). You are free to use this Thesis in any way that is permitted by the copyright and related rights legislation that applies to your use. For other uses you must obtain permission from the rights-holder(s) directly, unless additional rights are indicated by a Creative Commons license in the record and/ or on the work itself. This Thesis has been accepted for inclusion in WVU Graduate Theses, Dissertations, and Problem Reports collection by an authorized administrator of The Research Repository @ WVU. For more information, please contact researchrepository@mail.wvu.edu. 


\title{
The effect of moisture addition with a mold inhibitor on feed manufacture, pellet quality, and broiler performance
}

\author{
John M. Hott \\ Thesis submitted to the Davis College of Agriculture, Forestry and Consumer \\ Sciences in partial fulfillment of the requirements for the degree of
}

\author{
Master of Science \\ in \\ Animal and Nutritional Sciences \\ Joe S. Moritz, Ph.D., Chair \\ Hillar Klandorf, Ph.D. \\ Eugene E.D. Felton, Ph.D. \\ Department of Animal and Nutritional Sciences \\ West Virginia University \\ Morgantown, West Virginia \\ 2007
}

Keywords: Feed Manufacture, Pellet Quality, Broiler Performance

Copyright 2007 John M. Hott 


\section{Abstract \\ The effect of moisture addition with a mold inhibitor on feed manufacture, pellet quality, and broiler performance}

\section{John M. Hott}

Commercial broilers are typically fed pelleted diets because of the resulting improvements in bird performance and ease of transportation. Feed and feed manufacturing costs account for $60-70 \%$ of the total costs incurred in a broiler production system. Feed manufacturers are constantly searching for ways to decrease production costs while maintaining high pellet quality. Moisture addition at the mixer has been shown to increase pellet quality and decrease pellet mill energy consumption. However, past literature has incorporated high moisture addition levels that may be impractical in an industrial setting. The objective of this study was to determine the effects of moisture addition at the mixer plus a mold inhibitor on feed manufacture, pellet durability, and broiler performance variables using, perhaps, more practical inclusion levels of one, and two percent.

Three different inclusion levels of a moisture/mold inhibitor mixture $(0,1$, and $2 \%$ ) were added to corn soybean based diets at the mixer as top-dress additions and processed at a commercial and a pilot milling facility. Diets were then evaluated using feed manufacturing variables, pellet quality, broiler performance, and true metabolizable energy values corrected for nitrogen (TMEn). Moisture/mold inhibitor additions resulted in an increase in moisture percentages directly following manufacture. However, after a two day storage period, there were no differences in moisture percentage detected in diets manufactured at the pilot mill; however this was not true for diets manufactured commercially. Pellet durability was increased with moisture/mold inhibitor inclusion, for feed processed at the commercial mill; however, this trend was not observed for the feed processed at the pilot mill. This was likely due to differences in milling techniques such 
as: die length, conditioning temperature, corn particle size, and fat application. Relative electrical energy usage numerically decreased with increasing levels of moisture/mold inhibitor addition to feed processed at the pilot mill.

Performance data from feeding experiments indicate that the $1 \%$ and $2 \%$ diets manufactured commercially had positive impacts on broiler performance, as evident by improvements in body weight, live weight gain, and feed conversion ratio. However, diets manufactured at the research facility did not demonstrate these same improvements. Additionally, there were no differences in TMEn values between treatments regardless of manufacturing location. These findings indicate that moisture/mold inhibitor addition has the potential to improve broiler performance and decrease production costs, dependant upon milling technique. 


\section{Acknowledgements}

This research could not have been completed if where not for support received from friends, family and colleagues. First I would like to thank my major professor, Dr. Joe Moritz, who generously provided his time, knowledge, and guidance. He has not only been my mentor, but a good friend throughout my graduate career. I would also like to thank my committee members Dr. Hillar Klandorf and Dr. Eugene Felton for their support, encouragement, and advice these past few years. To my lab mates Nancy Buchanan, Sarah Cutlip, Amanda Rack, and Curran Gehring, words cannot express how grateful I am for all the long hours of hard work we have shared together. I sincerely hope that the friendships we have developed will continue to flourish throughout our lives. Acknowledgements also go out to my office mates who made our workplace feel so much like a home away from home. Finally I extend my deepest gratitude to my parents, Craig and Paula Hott, for their endless support, love and patience. 


\section{Table of Contents}

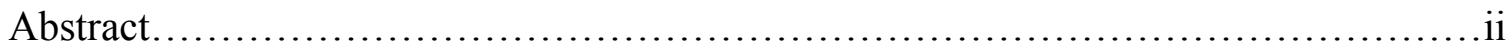

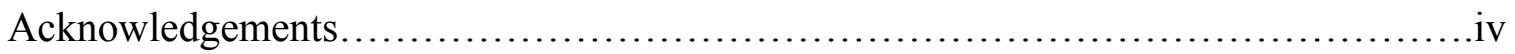

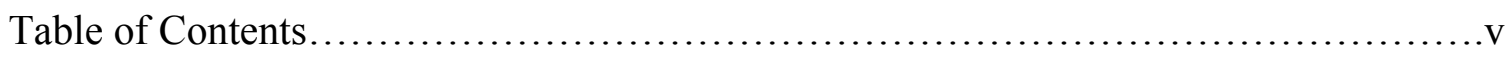

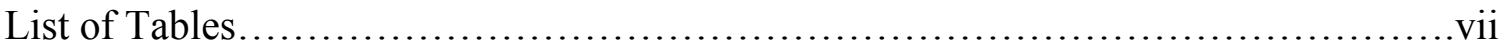

Literature Review..........................................................................

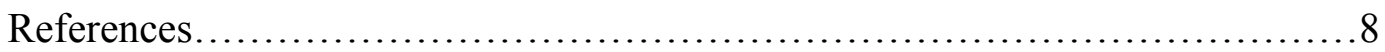

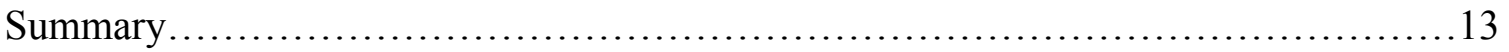

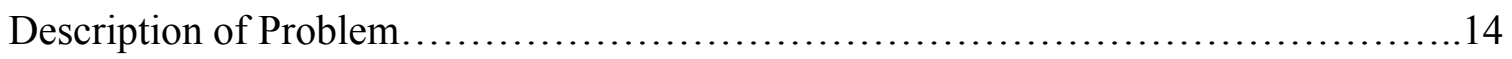

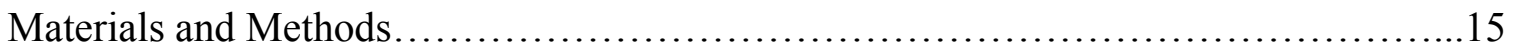

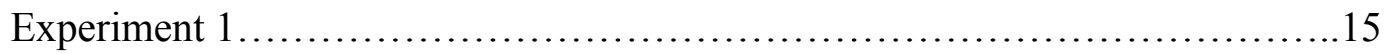

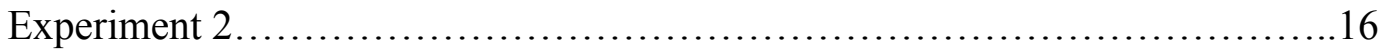

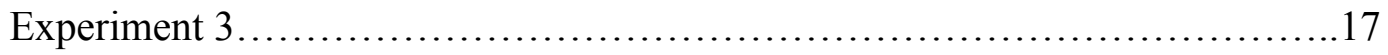

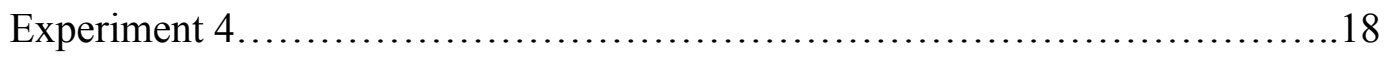

Statistical Analysis........................................................

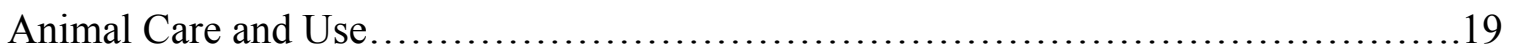

Results and Discussion........................................................ 19

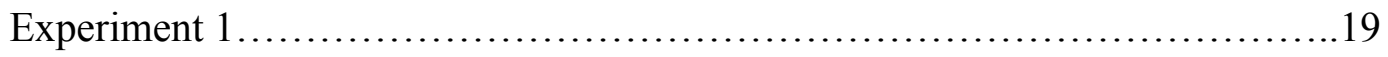

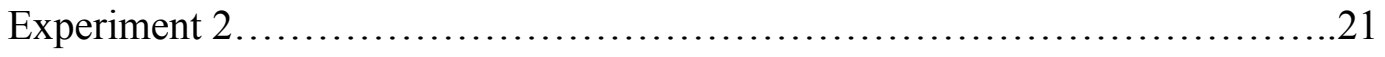

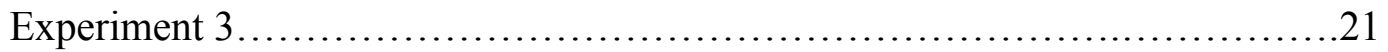

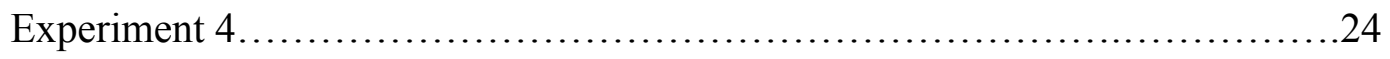

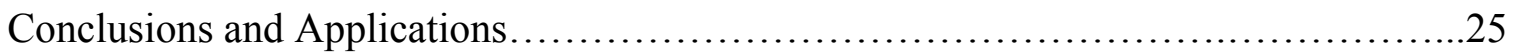




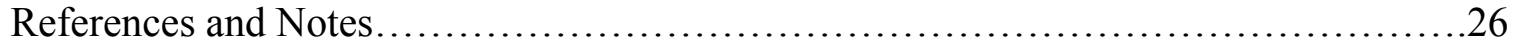

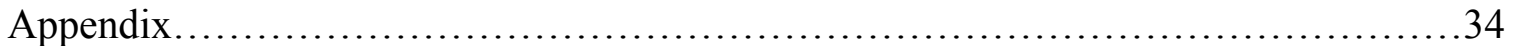




\section{List of Tables}

Table 1. Ingredient percentages of experimental diets.........................29

Table 2. Feed Manufacture Variables (Experiment 1) $\quad$ F........................

Table 3. 21-42d broiler performance variables (Experiment 2)................. 31

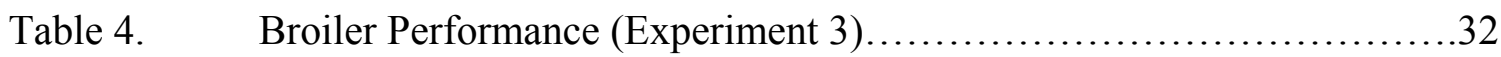

Table 5. Nitrogen Corrected True Metabolizable Energy (Experiment 4).........33 


\section{Literature Review}

Broiler production is the number one agricultural commodity in West Virginia, accounting for $31.4 \%$ of all agricultural products produced in the state. Approximately 88.5 million broilers were produced in the state in 2005 , accounting for 163.3 million dollars in revenue and ranking West Virginia $16^{\text {th }}$ in total U.S. broiler production (1). Behnke (2) estimates that $60-70 \%$ of the total costs incurred in a broiler production system are associated with feeding costs. Included in this estimate are both raw ingredient and manufacturing costs.

A broiler is a young chicken reared for meat and typically slaughtered at the age of six weeks. During the first three weeks of a broiler growing cycle, called the starter phase, they are typically presented with a mash or crumble diet, as the animals' small beak size limits their capacity to consume larger particles. The three to six week period is referred to as the grower/finisher phase. During this time, feed consumption and live weight gain are at their pinnacle and subsequently, the majority of manufacturing costs are incurred during this phase of production $(2,3)$.

During this phase, broilers are typically fed pelleted diets. Pelleted diets have been shown to improve broiler performance while aiding in transportation $(2,3)$. Previous reports indicate that pelleting can improve feed conversion by as much as $12 \%$ (2). Performance improvements have been accredited to decreases in: feed wastage, ingredient segregation, pathogenic organisms, and bird energy devoted to prehension (2, 3).

Steam conditioning utilized in the pelleting process provides heat and moisture necessary to gelatinize starch and bind feed particles. Starch gelatinization has been 
described as a process in which water in the form of saturated steam is diffused into the granule, causing swelling, increased heat, a declivity in crystallinity, and amylose leaching $(4,5)$. Double helices are then formed from the gelatinized starch, causing aggregation and creating semicrystalline regions. As the gelatinized starch cools it forms a gel, which may act as an adhesive, causing particle binding (6). The addition of high amounts of moisture may also lower the onset temperature required for starch gelatinization to occur (5).

In order to remain competitive and profitable, integrators and feed manufacturers must find economical ways to produce pellets of high quality. A high quality pellet is one that contains a complete, homogenous mixture of all dietary components and maintains its structural integrity after processing and during transportation. Common measurements used to assess pellet quality are the pellet durability index (PDI) and modified pellet durability index (MPDI). Pellet durability index values are generated using a 500g feed sample and a Pfost tumbling box. The fines are sifted from the sample and the whole pellets are then placed in the tumbling box, where they will spin at $50 \mathrm{rpm}$ for 10 minutes. These values are then expressed as the percentage of fines after tumbling to whole pellets before tumbling (7). Modified pellet durability index (MPDI) is an another means to quantify pellet quality, using the same technique involved in PDI with the addition of 5, $13 \mathrm{~mm}$ hex nuts added to the pre-tumbled pellets. This method is used to simulate many of the transportation and handling stresses incurred in a commercial setting.

One possible strategy to economically improve pellet quality is through the addition of moisture at the mixer. Fairchild and Greer (8) demonstrated that a 10\% increase in PDI value can be obtained by the addition of 3\% moisture to a corn-soybean 
based diet at the mixer, while simultaneously decreasing pellet mill energy usage by 2.3\%. Theses results are supported by Moritz et al. (9), who, using graded moisture addition levels of $0,2.5$ and 5\%, also noted improvements in pellet mill production rate, pellet quality, and relative electrical energy usage. Moritz and co-authors (10) also noted improvements in pellet quality when moisture was added to corn-soybean based diets to the mixer prior to processing and in a subsequent feeding trial, found that 3-6wk broiler feed efficiency was improved from $51.5 \%$ in diets with no added moisture to $52.9 \%$ in diets containing additional moisture. Feed efficiencies were adjusted to compensate for the nutrient dilution incurred by the addition of water to the diet. Moritz et al. (11) evaluated moisture addition of $5 \%$ with or without a commercial surfactant in two different energy-dense formulations, an NRC diet and an adjusted diet with a 5\% increase in all nutrients, prior to moisture addition. Interestingly, the authors used a soybean oil inclusion level of $6.5 \%$ in the adjusted formulation. Past literature has indicated that high inclusions of soybean oil may be detrimental to starch gelatinization and hence, pellet quality, as the fatty adjuncts present in the oil may inhibit solubilization and swelling by complexing with the amylose (6). The results of this experiment indicate that the addition moisture to adjusted density diets can increase pellet mill production rates while producing pellets of similar durability to that of NRC formulated diets without moisture addition and that moisture addition can counteract the negative effects associated with high oil inclusion. The type of moisture addition (with or without surfactant) had no effect on any of the variables measured. The addition of water to conventional cornsoybean based diets fed in mash form has also yielded favorable results, increasing body 
weight gain, feed intake, carcass weight, and carcass protein deposition when fed to growing broilers, (12).

The moisture addition strategy has raised concerns about the relationship between feeds with high moisture content and increased fungal and/or bacterial activity. Almost all cereal grains used for livestock production in the U.S. are exposed to some level of microbial contamination. Lacey (13) estimates that $10 \%$ of all grain losses worldwide are attributed to microbial contamination, but that number may reach as high as $50 \%$ in tropical areas. Fungi are the predominant microbes associated with cereal grains. While many fungi that may proliferate on standing crops require high moisture levels of $20 \%$ or more, varieties of fungi that are typically prevalent in stored feeds and grains thrive at moisture levels ranging from $12 \%$ to $18 \%$. Examples of fungi commonly found in stored grains are from the Aspergillus, Penicillium, and Fusarium genus (14). Mold spore growth and germination often elicit feed spoilage and the production of mycotoxins, both of which are detrimental to poultry production. Feed spoilage is the result of fungal consumption of carbohydrates as an energy source, which causes heating and decreases dry matter content of the feedstuff. Common mycotoxins present in cereal grains include: alfatoxins, sterigmatocystin, ochratoxin A, searalenone, T-2 toxin, and vomitoxin (14). The consumption of grains with high levels of mycotoxins, the result of fungal contamination, can cause mycotoxicosis. Mycotoxicosis has been described as a poisoning caused by the ingestion of grains that have been altered or damaged by microbial adulteration $(13,14,15)$. Lower concentrations of mycotoxins may be carcinogenic, mutagenic, oestrogenic, or teratogenic, resulting in decreased growth rate and suppressing the animal's immune system $(14,15)$. The consumption of contaminated 
feedstuffs may also contribute to the contamination of meat intended for human consumption, increasing the risk of human infection $(14,15)$. Tabib et al $(16)$ found that the process of pelleting conventional poultry diets reduces mold counts, while the addition of a mold inhibitor further increases these effects.

Commercial mold inhibitors have been available to manufactures for several years. These products are primarily composed of propionic acid and other organic acids. Organic acids are absorbed through the microbial cell wall where they dissociate due to the lower $\mathrm{pH}$ in the cytoplasm. The resulting release of hydrogen disrupts cytoplasmic function and prohibits growth $(18,19)$. Other organic acids commonly used for their fungistatic properties include but are not limited to: benzoic acid, butyric acid, and formic acid. Using a mixture or blend of organic acids is advantageous because they have a synergistic effect on each other. In vitro studies using combinations of formic and propionic acids indicate that the two are more effective together, on a weight basis, than either one of the two acids separately.

The application of propionic acid and other organic acids as feed preservatives has been well documented $(20,21)$. Paster (20) evaluated efficacy of propionic acid in preserving poultry feed in a commercial setting. Organic acids have proved effective in prolonging storage time while simultaneously improving performance characteristics of cattle, particularly feed conversion ratio. Perry (21) found that cattle given high moisture corn diets treated with a mixture of propionic and acetic acids yielded $6 \%$ increases in weight gain while having no effects on feed consumption.

Past research has indicated that the majority of dietary propionic acid and other volatile fatty acids are metabolized and absorbed before Meckel's diverticulm, meaning 
that acid treatment of feed would have little effect on the intestine and ceca $(22,23)$. Humes and co-authors (22), using radio labeled propionic acid, observed that $83 \%$ of the propionic acid administered to chicks remained as unchanged propionic acid in the forgut up to 15 minutes post gavage, leading the authors to speculate that providing propionic acid as a feed additive would result in the continual presence of propionic acid in the foregut. However, Tabib et al. (24) did note that supplementing broiler diets with buffered propionic acid did significantly reduce Escherichia coli counts in the duodenum, jejunum, and the ileum, while reducing the number of salmonellae present on postchill carcasses of birds periodically dosed with Salmonella. Additionally Dibner and Buttin (25) postulated that organic acids may improve protein and energy digestibility by: reducing microbial competition with the host for nutrients, lowering incidence of subclinical infections and secretion of immune mediators, reducing ammonia and other growth-depressing microbial metabolites.

A major concern with the moisture addition strategy is the potential for nutrient dilution and its negative impacts on broiler performance. The degree of nutrient dilution can be evaluated using the true metabolizable energy (TME). To determine TME, birds, typically Single Comb White Leghorns, are housed in individual cages and withheld feed for a period of time. Birds are then precision fed a specific amount of the diet or feedstuff being evaluated, placed back in their respective cages, and excreta is collected. A control bird must also be used to determine endogenous excreta energy losses. Control birds are subjected to both the withdraw and collection periods; however, they receive no feed in order to measure endogenous fecal output. The length of feed withdraw and collection periods vary. Sibbald (26) suggests withholding feed for $21 \mathrm{hrs}$ and collecting excreta for 
$24 \mathrm{hrs,}$ while McNabb and Blair (27) recommend $48 \mathrm{hrs}$ for both periods. After excreta collection, samples are freeze dried and ground. Gross energy of both the feedstuff and the excreta sample is then determined by bomb calorimetery. Nitrogen content is measured using the Kjeldahl method and is used to correct the TME equation for nitrogen retention, as this varies with age and species. The following mathematical equation can then be used to determine TMEn:

TMEn $=$

$\underline{((\text { GE Feed x Intake })-((\text { GE Excreta x Output })+/-(\text { N Retention x 8220) })-(\text { Endogenous GE x Output })))}$ Feed Intake

True metabolizable energy is reported as $\mathrm{kcal} / \mathrm{kg}$ and nutrient dilution would be evident as this would cause a decrease in TME values. 


\section{References}

1. West Virginia Field Office, USDA-NASS, 2006. West Virginia Agriculture Statistics. Annual Bulletin Number 37. http://www.nass.usda.gov/Statistics by State/West Virginia/Publications/Annual Statistical_Bulletin/Bulletin2006-All.pdf. Accessed July 2007.

2. Behnke, K. C. 1994. Factors affecting pellet quality. Pages 44-54 in Proc. Maryland Nutr. Conf. Feed Manuf., College Park, MD. Maryland Feed Ind. Counc. and Univ. Maryland, College Park

3. Briggs, J.L., D.E. Maier, B.A. Watkins, and K.C. Behnke. 1999. Effect of ingredients and processing parameters on pellet quality. Poult. Sci. 78: 1464-1471.

4. Hoover, R. 1995. Starch retrogradation. Food Rev. Int. 11:331-346.

5. Parker, R. and S.G. Ring. 2001. Mini Review: Aspects of the Physical Chemistry of Starch. J. Cereal Sci. 34: 1-17.

6. Lund, D. 1984. Influence of time, temperature, moisture, ingredients and processing conditions on starch gelatinization. CRC Crit. Rev. Food Sci. Nutr. 20:249-273.

7. American Society of Agricultural Engineers. 1997. ASAE S269.4. Cubes, pellets, and crumbles - Definitions and methods for determining density, durability, and moisture. Standards 1997. Am. Soc. Agric. Eng., St. Joseph MI.

8. Fairchild, F. and D. Greer. 1999. Pelleting with precise mixer moisture control. Feed Int. 20 (8): 32-36. 
9. Moritz, J.S., K.R. Cramer, K.J. Wilson, and R.S. Beyer. 2003. Feed manufacture and feeding of rations with graded levels of added moisture formulated at different densities. J. Appl. Pout. Res. 12:371-381.

10. Moritz, J. S., R. S. Beyer, K. J. Wilson, K. R. Cramer, L. J. McKinney, and F. J. Fairchild. 2001. Effect of moisture addition at the mixer to a corn-soybean-based diet on broiler performance. J. Appl. Poult. Res. 10: 347-353.

11. Moritz, J. S., K. J. Wilson, K. R. Cramer, R. S. Beyer, L. J. McKinney, W. B. Cavalcanti, and X. Mo. 2002. Effect of formulation density, moisture and surfactant on feed manufacturing, pellet quality and broiler performance. J. Appl. Poult. Res. 11:155-163.

12. Yalda, A.Y. and J.M. Forbes. 1995. Food intake and growth in chickens given food in the wet form and without access to drinking water. Brit. Poult. Sci. $36: 375-369$.

13. Lacy, John, Nannapaneni Ramakrishna, and Alison Hammer.1991. Grain Fungi. In Handbook of Applied Mycology Vol. 3. D.K. Arora, K.G.Mukerji, E.K.Marth ed.

14. Smith, J.E. 1982. Mycotoxins and poultry management. World's Poult. Sci. J. 38(3):201-212.

15. Rusul, Gulam and Elmer H. Marth. 1988. Food additives and plant components control growth and aflatoxin production by toxigenic aspergilli: A review. Mycopathologia. 101: 13-23.

16. Vanderwal, P. 1979. Salmonella control of feedstuffs by pelleting or acid treatment. World's Poult. Sci. J. 35(2):70-78. 
17. Tabib, Z., F. Jones, and P.B. Hamilton. 1984. Effect of pelleting poultry feed on the activity of molds and mold inhibitors. Poult Sci. 63:70-75.

18. Stratford, M, and P.A. Anslow. 1996. Comparison of the inhibitory action on Saccharmoyces cerevisiae of weak-acid preservatives, uncouplers, and mediumchain fatty acids. FEMS Microbiology Letters. 142: 53-58.

19. Van Immerseel, F., J.B. Russell, M.D. Flythe, I. Gantois, L Timbermont, F. Pasmans, F. Haesebrouck, and R. Ducatelle. 2006. The use of organic acids to combat Salmonella in poultry: a mechanistic explanation of the efficacy. Avian Pathology. 35(3): 182-188.

20. Paster, N. 1979. A commercial study of the efficiency of propionic acid and acid and calcium propionate as fungistats in poultry feed. Poult Sci. 58:572-576.

21. Perry, T.W., 1972. Molds and mycotoxins: Improving feed efficiency with organic acids. Farm Tech. 28(5):42-45.

22. Hume, Michael E., Donald E. Corrier, G. Wayne Ivie, and John R. Deloach. 1993. Metabolism of $\left[{ }^{14} \mathrm{C}\right]$ propionic acid in broiler chicks. Poult Sci. 786-793.

23. Bolton, W., and W.A. Dewar, 1964. The digestibility of acetic, propionic, and butyric acids by the fowl. Br. Poult. Sci. 6:103-105

24. Izat, A.L., N. M. Tidwell, R.A. Thomas, M.A. Reiber, M.H. Adams, M. Colberg, and P.W. Waldroup. 1990. Effects of propionic acid in the diets on the performance of broiler chickens and on the microflora of the intestine and carcass. Poult. Sci. 69: 818-826. 
25. Dibner, J.J. and P. Buttin. 2002. Use of organic acids as a model to study the impact of gut microflora on nutrition and metabolism. J. Appl. Poult. Res. 11: $453-463$.

26. Sibbald, I.R. (1976). A bioassay for true metabolizable energy in feedingstuffs. Poult Sci. 55: 303-308.

27. Mcnab, J.M. and J.C. Blair. 1988. Modified assay for true and apparent metabolisable energy based on tube feeding. Br. Poult. Sci. 29:697-707. 
The effect of moisture addition with a mold inhibitor on pellet quality, feed manufacture, and broiler performance

\author{
Hott, J.M., N.P. Buchanan, S.E. Cutlip and J.S. Moritz ${ }^{1}$ \\ Division of Animal and Nutritional Sciences, West Virginia University, Morgantown WV \\ 26506
}

Key Words: Feed Manufacture, Pellet Quality, Broiler Performance

Primary Audience: Feed Mill Managers, Broiler Producers, Nutritionists, Researchers

${ }^{1}$ To whom correspondence should be addressed: Joe.Moritz@mail.wvu.edu 


\section{SUMMARY}

Three different inclusion levels of a moisture/mold inhibitor mixture $(0,1$, and $2 \%)$ were added to corn-soybean based diets at the mixer as top-dress additions and processed at a commercial and a pilot milling facility. Diets were then evaluated using feed manufacturing variables, pellet quality, broiler performance, and true metabolizable energy values corrected for nitrogen (TMEn). Moisture/mold inhibitor additions resulted in an increase in moisture percentages directly following manufacture. After a two day storage period, there were no differences in moisture percentage detected in diets manufactured at the pilot mill; however this was not true for diets manufactured commercially. Pellet durability was increased with moisture/mold inhibitor inclusion, for feed processed at the commercial mill; however, this trend was not observed for the feed processed at the pilot mill. This was likely due to differences in milling techniques such as: die length, conditioning temperature, corn particle size, and fat application. Relative electrical energy usage numerically decreased with increasing levels of moisture/mold inhibitor addition to feed processed at the pilot mill.

Performance data from feeding experiments indicate that the $1 \%$ and $2 \%$ diets manufactured commercially had positive impacts on broiler performance, as evident by improvements in body weight, live weight gain, and feed conversion ratio. However, diets manufactured at the pilot mill did not demonstrate similar improvements. Additionally, there were no differences in TMEn values among treatments regardless of manufacturing location. These findings indicate that moisture/mold inhibitor addition has the potential to improve broiler performance and decrease production costs, dependant upon milling technique. 


\section{DESCRIPTION OF PROBLEM}

Commercial broilers are typically fed pelleted diets because of the resulting improvements in feed handling and bird performance (1). There are several attributes of pelleted diets that may account for performance improvements including reductions in prehension energy expenditure, feed spillage and ingredient segregation $(1,2)$. In order to achieve these positive attributes, manufacturers must incorporate pelleting techniques that will yield high quality pellets. Past research has demonstrated that improvements in pellet quality can directly improve broiler feed conversion ratio $(3,4)$. Feed manufacturers are constantly searching for ways to improve pellet quality while minimizing production costs. A possible solution may be to incorporate moisture into mash diets at the mixer. Fairchild and Greer (5) observed an improvement in pellet durability and a decrease in pellet mill energy consumption when moisture was added to the diet at the mixer. Moisture addition levels used in that study ranged from 1 to $4 \%$. Moritz et al. $(6,7,8)$ observed similar improvements in pellet quality and electrical energy usage using moisture addition levels of $2.5 \%$ and $5 \%$.

The addition of water to mash diets may also produce negative effects, mainly nutrient dilution and mold spore proliferation. These effects have the potential to negatively impact broiler performance. To combat the problem of mold contamination, commercial mold inhibitors have been developed. Traditionally these substances have been applied in a powder form; however the addition of water at the mixer has led to the development of new products that allow for liquid application (9).

Past research has investigated moisture addition at high levels (2.5\% and 5.0\%) on broiler performance and feed manufacture $(6,7,8)$; however, these high levels of 
inclusion may be impractical in the commercial broiler industry, as nutrient dilution and mold spore proliferation become greater concerns as the moisture content of the feed increases. Additionally, high dietary moisture levels create challenges in reaching conditioning temperatures of $82^{\circ} \mathrm{C}$ without choking the pellet die, or decreasing the frictional force necessary for mash extrusion through the pellet die. These effects may be further exacerbated when corn moisture levels are high and ambient air temperatures are low. The objective of this study was to determine the effects of moisture addition at the mixer plus a mold inhibitor on feed manufacture, pellet durability, and broiler performance variables using, perhaps, more practical inclusion levels of one, and two percent.

\section{MATERIALS AND METHODS}

\section{Diet Formulation and Feed Manufacture}

\section{(Experiment One)}

Three broiler grower diets were manufactured at the West Virginia University pilot feed mill. Diets consisted of a corn-soybean based control formulation (CON) as well as the control formulation with one and two percent additions of a water/mold inhibitor amalgam (Table 1). A Latin square design was utilized to manufacture the three diets on three consecutive days. A $544 \mathrm{~kg}(1200 \mathrm{lb})$ basal diet was mixed and divided into three $181 \mathrm{~kg}(400 \mathrm{lb})$ aliquots from which experimental diets were formed, for each day of processing. Corn was ground to 1,000 microns prior to pelleting. Diet manufacture was blocked by day and run order. The mold inhibitor (10) was mixed with water at a 95:5 (water: mold inhibitor) ratio and added as a top-dressing to the control formulation. Top dress application took place in a single-screw vertical mixer (11) using a garden 
sprayer set to deliver a fine mist. The diet was then allowed to mix for 15 minutes to ensure uniform distribution. Mash diets were conditioned at $82^{\circ} \mathrm{C}\left(180^{\circ} \mathrm{F}\right)$ using saturated steam with an incoming pressure of $262 \mathrm{kPa}(38 \mathrm{psig})$ in a short-term conditioner [0.31 x $1.30 \mathrm{~m}(1.02 \times 4.25 \mathrm{ft})$, and ten second retention time]. A California Pellet Mill (12) with a 4.76 x $44.96 \mathrm{~mm}$ (3/16 x $1.77 \mathrm{in})$ die was used for pellet formation. Pellets were then cooled for 1.25 minutes with a horizontal, forced ambient air cooler. The average ambient air temperature and relative humidity during manufacture was $18^{\circ} \mathrm{C}\left(64^{\circ} \mathrm{F}\right)$ and $68 \%$ respectively. Throughout manufacture, production rate and pellet mill energy consumption were monitored. Energy meters were not in place until the last day of manufacture, hence relative electrical energy values are reported as descriptive data. Immediately following manufacture, pellets were analyzed to determine: moisture loss over a 3 day storage period, pellet durability index (PDI), modified pellet durability index (MPDI), fines \%, and bulk density (Table 2) (13). All samples were analyzed in duplicate, with the averages providing a mean for each replicate.

\section{Broiler Performance}

\section{(Experiment Two)}

Four hundred eighty, day-old, straight run Cobb 500 broilers were randomly assigned to 30 pens containing 16 birds per pen. Bird density was based on summer rearing management. Each pen contained two inches of fresh pine shavings, two Ziggity ${ }^{\circledR}$ nipple drinkers, and hanging pan feeders, providing birds ad libitum access to feed and water. Supplemental feeding trays and water founts were provided during the initial seven day period to ensure adequate consumption. Lighting was continual from 
$\mathrm{d} 1-3,23 \mathrm{hr}$ from $\mathrm{d} 4-7,20 \mathrm{hr}$ from d8-24, and $23 \mathrm{hr}$ for the remainder of the study. Initial starting temperature was set at $32.8^{\circ} \mathrm{C}\left(90^{\circ} \mathrm{F}\right)$ for the first week and was decreased by $2.8^{\circ} \mathrm{C}\left(5^{\circ} \mathrm{F}\right)$ each week thereafter to maximize bird comfort, until a temperature of $21^{\circ} \mathrm{C}$ $\left(70^{\circ} \mathrm{F}\right)$ was reached.

An industry formulated (14) mash starter diet was fed during the initial 21 day pretest period (Table 1). On day 21, birds were individually weighed and redistributed evenly by weight. Using a randomized complete block design, the three grower diets manufactured in experiment one were randomly assigned within ten blocks of three pens. Blocks were designated by location in the grow-out facility. Diets were fed approximately one week after manufacture. The study was ended on day 42 . Beginning pen weight as well as 21-42 day live weight gain, feed consumption, and feed conversion ratio were determined (Table 3 ).

\section{Broiler Performance}

(Experiment three) $\backslash$

Nine hundred forty-five, day old straight run Cobb 500 broilers were randomly allocated to 45 pens containing 21 birds per pen. Bird density was based on winter rearing management. Pens were assigned to one of three similarly formulated treatments as in Experiment one (Table 1); however, these diets were manufactured at a commercial mill (14) and the moisture/mold inhibitor mixture was fed to broilers throughout the starter and grower phase. The commercial mill utilized a 100hp Century California pellet mill with a 6 ton/hr capacity and a 4 second short term conditioner to process diets. Pellets were extruded through a $4.37 \times 63.5 \mathrm{~mm}(11 / 64 \times 2.5$ in.) die with a steam

pressure and temperature of $241 \mathrm{kpa}(35 \mathrm{psig})$ and $68^{\circ} \mathrm{C}\left(155^{\circ} \mathrm{F}\right)$ respectively. Corn was 
ground to 500 microns prior to pelleting and mixed for 4 minutes using a 3 ton horizontal ribbon mixer. Fat was added post-pelleting. Diets were stored approximately 2 wks prior to feeding. Dietary treatments were replicated 15 times and blocked by location in the grow-out facility. Rearing conditions were identical to those described in Experiment two.

Dietary treatments were presented to birds in a crumbled form from days 1-21 and in a pelleted form days 21-42. Beginning pen weight was determined as well as live weight gain, feed intake, and feed conversion ratio for the 1-21 and 21-42d periods. Feed manufacturing variables examined included moisture \%, PDI and MPDI; however, feed manufacture was not replicated hence, feed manufacture variables were reported as descriptive data.

\section{$T M E_{n}$}

\section{(Experiment Four)}

Experiment four utilized 14 cecectomized Single Comb White Leghorn roosters divided into two blocks with seven treatments per block. Treatments consisted of the six diets manufactured in Experiment one and three, as well as a pelleted cornstarch control to determine endogenous excreta energy. Birds were placed in $305 \times 508 \mathrm{~cm}(12 \times 20 \mathrm{in}$.) raised wire cages and were precision fed randomly assigned diets in a manner similar to Sibbald (15). This procedure was repeated after a 2 week resting period to provide additional replications for statistical analysis. Excreta samples were weighed, dried (16) and ground through a $1 \mathrm{~mm}$ screen (17). Dried samples were analyzed for gross energy (18) and nitrogen content (19). True metabolizable energy corrected for nitrogen $\left(\mathrm{TME}_{\mathrm{n}}\right)$ was calculated on an as is basis. 


\section{Statistical Analysis}

Data was analyzed using the GLM procedure of SAS (20) to determine the effect of water/mold inhibitor addition on feed manufacturing and broiler performance variables. Multiple comparisons between mean values were made using Fisher's least significant difference test. Linear and quadratic regression analysis was also performed among treatments. For all analyses performed, $\alpha$ was 0.05 . One way ANOVA was utilized to examine possible effects and interactions of moisture addition and mill location/technique on TMEn.

\section{Animal Care and Use}

All animals and facilities were maintained in compliance with guidelines established by the West Virginia University Animal Care and Use Committee, ACUC protocol number 06-0502.

\section{RESULTS AND DISCUSSION}

\section{Experiment One}

Moisture $\%$ on the day of manufacture increased incrementally $(\mathrm{P}<0.05)$ in treatments with the moisture/mold inhibitor addition (Table 2). After storage for one day, there was still a linear increase among treatments in feed moisture percentage $(\mathrm{P}=0.046)$; however, after two days of storage, there were no differences $(\mathrm{P}>0.05)$ detected in feed moisture percentage. These results indicate that pellet moisture had equilibrated with atmospheric moisture in two days of storage. Furthermore, moisture addition from steam conditioning diminished over time, as evident from control diet measurements.

Pellet durability and modified pellet durability were not affected by the addition of the moisture/mold inhibitor amalgam (Table 2). These results contradict results 
obtained by Fairchild and Greer (5) as well as Moritz and coauthors $(6,7,8)$, who noted significant increases in PDI and MPDI values as mash moisture content was increased. However, it is important to note that the PDI and MPDI values in the control diet were exceptionally high to begin with ( 89.54 and 81.96 respectively), leaving little room for improvement in pellet quality. A possible explanation for the inconsistencies between past studies and the current study is the variation among pellet dies used during feed manufacture. The current study utilized a $44.96 \mathrm{~mm}(1.77 \mathrm{in})$ thick die with $4.76 \mathrm{~mm}$ (3/16 in) diameter die openings. The ratio of die thickness to opening diameter was 9.44. In past studies a $31.75 \mathrm{~mm}(1.25 \mathrm{in})$ thick die with $3.97 \mathrm{~mm}$ (5/32 in) die openings was used. The ratio of die thickness to opening diameter was 8 . Pellet manufacturers recommend a die thickness to opening diameter ratio of 10 in order to produce high quality pellets with high grain rations as would be typical for broiler diets (21). Likewise, dietary treatment had no effect $(\mathrm{P}>0.05)$ on bagged fines, cooler fines, and total fines percentages. In contrast, Moritz and coauthors (7) observed decreases in bagged fines percentage with increasing moisture additions. Production rate was also not affected by treatment $(\mathrm{P}>0.05)$. Again, these results differ from past research $(5,8)$ that demonstrated an increase in production rate as mash moisture levels increased. Pellet mill electrical energy usage decreased numerically from $4.42 \mathrm{kwh} / \mathrm{Mton}$ in the control, to 4.16 $\mathrm{kwh} / \mathrm{Mton}$ and $3.87 \mathrm{kwh} / \mathrm{Mton}$ in the $1 \%$ and $2 \%$ diets respectively. These results are in agreement with Fairchild and Greer as well as Moritz and coauthors $(5,7,8)$ who observed similar reductions in pellet mill energy usage using graded moisture addition levels. Much of the past research utilized moisture addition levels ranging from $2.5 \%$ to $5 \%$. The 
lower moisture addition levels of the current study may also account for discrepancies observed in feed manufacturing variables between these studies.

\section{Experiment Two}

The addition of 1 and 2\% moisture/mold inhibitor did not affect live weight gain or feed consumption $(\mathrm{P}>0.05)$ and consequently had no effect on feed conversion ratio $(\mathrm{P}>0.05)$. Dietary treatment also had no effect on mortality \% ( $\mathrm{P}>0.05$, Table 3$)$.

Previous research has indicated that moisture addition at the mixer to cornsoybean-based diets improved broiler performance $(6,7,8)$. These results have been linked largely to improvements in pellet quality; however, in the present study, pellet quality remained unchanged with increasing moisture additions. This observation could have been the result of low moisture addition or variation among milling techniques such as pellet die use that may supercede moisture addition effects on pellet quality. Interestingly, after a two day storage period, any moisture added during manufacturing was not present, indicating that the nutrient profile of the diets was similar, resulting in similar performance characteristics when the diets were fed.

\section{Experiment Three}

Diets manufactured at the commercial facility were of high pellet quality with PDI and MPDI values being 93, 97, 96 and 87, 92, 91 for the control, $1 \%$ and 2\% diets respectively (Table 4). Corn particle size was smaller in Experiment 3 compared to that used in Experiment 1 (500 $\mu \mathrm{m}$ and $1000 \mu \mathrm{m}$ respectively). Smaller corn particle size has been linked to improvements in pellet quality (22). Pellet die length: diameter ratio was 14.5 in Experiment 3 compared to 9.44 in Experiment 1. A larger length: diameter ratio would require more frictional force to extrude pellets through the die, and likely 
increased starch gelatinization and consequently pellet quality. Moisture percentages of stored pellets were higher for diets manufactured in Experiment 3 and may indicate an increase in gelatinized starch. Past studies have correlated increasing moisture content of feed with an increase in starch gelatinization $(6,7)$. Post pellet fat application and low steam conditioning temperature may also have permitted greater starch gelatinization with moisture addition at the mixer and thus improved pellet quality. Increases in starch gelatinization have been linked to improvements in PDI $(6,7)$. Water may act as a prerequisite for starch gelatinization (23). Previous studies have observed that increasing the water to starch ratio in the diet significantly increases the amount of starch gelatinization in the final pellet $(7,24)$. However, proper water: starch ratios necessary for complete gelatinization are never reached in a short term conditioning system. Thus, heat generated within the conditioning/pelleting system may have a greater impact on partial starch gelatinization and pellet quality. The addition fat at the mixer, the technique used in Experiment 1, may decrease opportunities for starch to gelatinize as well as increase die lubrication, decrease frictional force in the die and additionally decrease starch gelatinization and protein denaturation, both conformational changes that could affect pellet durability. The lower conditioning temperature used in Experiment 3 reduced the amount of water added to the feed in the conditioner, thus decreasing lubrication and increasing frictional force in the die, potentially increasing starch gelatinization. The improvement in pellet quality relative to the high quality control formulation was remarkable. Broilers receiving diets containing the moisture/mold inhibitor mixture performed better than those receiving control diets (Table 4). Inclusion levels of $2 \%$ resulted in an increase $(\mathrm{P}<0.05)$ in 21-42 day body weight and live weight gain compared 
to control diets. However, birds that consumed the $1 \%$ diet demonstrated superior feed conversion ratios $(\mathrm{P}<0.05)$ compared to birds receiving both the control and $2 \%$ diets. It is possible that the variations in performance data between the $1 \%$ and $2 \%$ diets were due to interactions of pellet quality and nutrient dilution. The $2 \%$ diet demonstrated an increase in PDI and retained more moisture relative to the control. Consequently, birds consuming this diet increased feed intake and gained more weighed. Moisture percentage for the $1 \%$ diet was similar to the control, thus decreased feed conversion ratio was likely due to improvements in pellet quality. Research conducted by Cutlip and co-authors (25) demonstrated similar results, noting significant improvements in broiler performance when PDI values were increased by 4 points in a high pellet quality range ( 89 vs. 93 ). The authors suggest that improvements in pellet quality above $90 \%$ may dramatically influence broiler performance. These performance improvements may be attributed to the reduction in energy expenditure during prehension $(1,26)$. Experiments two and three differed in feed manufacturing location/technique and the incorporation of the moisture/mold inhibitor mixture throughout the starter and grower periods. This prolonged consumption of the moisture/mold inhibitor amalgam could have been additive to benefits associated with improved pellet quality and the improvements observed in broiler performance variables experienced in experiment three. Past research has demonstrated improvements in broiler performance when organic acids were added to $\operatorname{diets}(27,28)$. 


\section{Experiment Four}

Results from the TMEn assay indicate that there were no differences $(\mathrm{P}>0.05)$ in metabolizable energy values among diets from experiments two and three (Table 4). Further statistical evaluation using one way ANOVA analysis indicates that neither moisture nor milling location, or a moisture by milling location interaction elicited a significant effect on TMEn values. Values obtained through TMEn assay were higher than calculated values, likely due to the $24 \mathrm{hr}$ fasting and collection periods used in this assay. McNab and co-authors (29) recommend a $48 \mathrm{hr}$ fasting and $48 \mathrm{hr}$ fecal collection period to allow for the clearance of residual feed in the gastrointestinal tract. The $24 \mathrm{hr}$ fasting/collection period was chosen for this study because birds used had been previously trained for this procedure. Diets used in the two studies were nutritionally comparable based on the rooster model, indicating that the performance differences observed between experiments two and three may not have been related to digestible energy. 


\section{CONCLUSIONS AND APPLICATIONS}

1. In Experiment 1, addition of moisture/mold inhibitor increased moisture percentage of feed on day of manufacture; however, diets equilibrated after a two day storage period, thus nutrient profiles were not diluted.

2. Relative electrical energy usage was numerically lowered with increasing additions of moisture/mold inhibitor, suggesting a decreased pellet production cost.

3. Moisture/mold inhibitor addition improved broiler LWG, BW, and FCR in Experiment 3, likely due to the improvements obtained in pellet quality and increased exposure to the organic acids present in the mold inhibitor throughout the starter and grower periods.

4. Pellet quality improvements associated with moisture addition at the mixer are dependent on milling technique. 


\section{References and Notes}

1. Behnke, K. C. 1994. Factors affecting pellet quality. Pages 44-54 in Proc. Maryland Nutr. Conf. Feed Manuf., College Park, MD. Maryland Feed Ind. Counc. and Univ. Maryland, College Park.

2. Briggs, J.L., D.E. Maier, B.A. Watkins, and K.C. Behnke. 1999. Effect of ingredients and processing parameters on pellet quality. Poult. Sci. 78: 1464-1471.

3. Nir, I., Y. Twina, E. Grossman, and Z. Nitsan. 1994. Quantitative effects of pelleting on performance, gastrointestinal tract and behavior of meat-type chickens. Br. Poult. Sci. 33:589-602.

4. Moran, E.T. Jr. 1989. Effect of pellet quality on the performance of meat birds. Pages 87-108 in Recent Advances in Animal Nutrition. W. Haresign and D.J.A. Cole, ed. Butterworths, London.

5. Fairchild, F. and D. Greer. 1999. Pelleting with precise mixer moisture control. Feed Int. 20(8):32-36.

6. Moritz, J. S., R. S. Beyer, K. J. Wilson, K. R. Cramer, L. J. McKinney, and F. J. Fairchild. 2001. Effect of moisture addition at the mixer to a corn-soybean-based diet on broiler performance. J. Appl. Poult. Res. 10:347-53.

7. Moritz, J. S., K. J. Wilson, K. R. Cramer, R. S. Beyer, L. J. McKinney, W. B. Cavalcanti, and X. Mo. 2002. Effect of formulation density, moisture and surfactant on feed manufacturing, pellet quality and broiler performance. J. Appl. Poult. Res. 11:155-163. 
8. Moritz, J.S., K.R. Cramer, K.J. Wilson, and R.S. Beyer. 2003. Feed manufacture and feeding of rations with graded levels of added moisture formulated at different densities. J. Appl. Pout. Res. 12:371-381.

9. Anitox Corp. Lawrenceville, GA

10. Fungex ${ }^{\circledR}$ mold inhibitor. Contains $30 \%$ propionic acid, $30 \%$ butyric acid and 40 $\%$ aqueous ammonia solution (buffering agent). Manufactured by Anitox Corp. Lawerenceville, GA.

11. Weigh-Tronix single screw vertical mixer with a 1 ton capacity.

12. California Pellet Mills Inc., Crawfordsville, IN 47933

13. American Society of Agricultural Engineers. 1997. ASAE S269.4. Cubes, pellets, and crumbles - Definitions and methods for determining density, durability, and moisture. Standards 1997. Am. Soc. Agric. Eng., St. Joseph MI.

14. MFA Inc. $225 \mathrm{~S}$ Jefferson Ave Lebanon, MO.

15. Sibbald, I.R. (1976). A bioassay for true metabolizable energy in feedingstuffs. Poult Sci. 55: 303-308.

16. Virtis Freezemobile 12SL, Virtis Co., Gardiner, NY

17. Cyclotec 1093 sample mill, Foss Tecator, Eden Prairie, MN.

18. Isoperibol oxygen bomb calorimeter model 1266, Parr Instrument Co., Moline, IL.

19. Kjeltec Auto 1030 analyzer, Foss Tecator, Eden Prairie, MN.

20. SAS Institute. 2005. SAS system for Windows V8

21. California Pellet Mills Inc., 2007. Personal communication. Crawfordsville, IN. 
22. Reece, F.N., B.D. Lott, and J.W. Deaton. 1986. Effects of environmental temperature and corn particle size on response of broilers to pelleted feed. Poult. Sci. 65:636-641.

23. Thomas, M., T. van Vliet, and V.F.B. van der Poel. 1998. Physical quality of pelleted animal feed 3. Contribution of feedstuff components. Anim. Feed Sci. Technol. 70: 59-78.

24. Lund, D. 1984. Influence of time, temperature, moisture, ingredients and processing conditions on starch gelatinization. CRC Crit. Rev. Food Sci. Nutr. 20:249-273.

25. Cutlip, S.E., J.M. Hott, N.P. Buchanan, A.L. Rack, J.D. Latshaw, and J.S. Moritz. 2007. The effect of steam conditioning practices on pellet quality and growing broiler nutritional value. J. Appl. Poult. Res. (In Press)

26. Jensen, L.S., L.H. Merrill, C.V. Reddy, and J. McGinnis. 1962. Observations on eating patterns and rate of food passage of birds fed pelleted and unpelleted diets.

27. Izat, A.L., N. M. Tidwell, R.A. Thomas, M.A. Reiber, M.H. Adams, M. Colberg, and P.W. Waldroup. 1990. Effects of propionic acid in the diets on the performance of broiler chickens and on the microflora of the intestine and carcass. Poult. Sci. 69: 818-826.

28. Vieira, S.L., and E.T. Moran, Jr. 1998. Broiler yields using chicks from extremes in breeder age and dietary propionate. J. Appl. Poult. Res. 7: 320-327.

29. McNab, J.M and J.C. Blair. 1988. Modified Assay for true and apparent metabolisable energy based on tube feeding. Br. Poult. Sci. 29:697-70 
Table 1: Ingredient percentages of experimental diets.

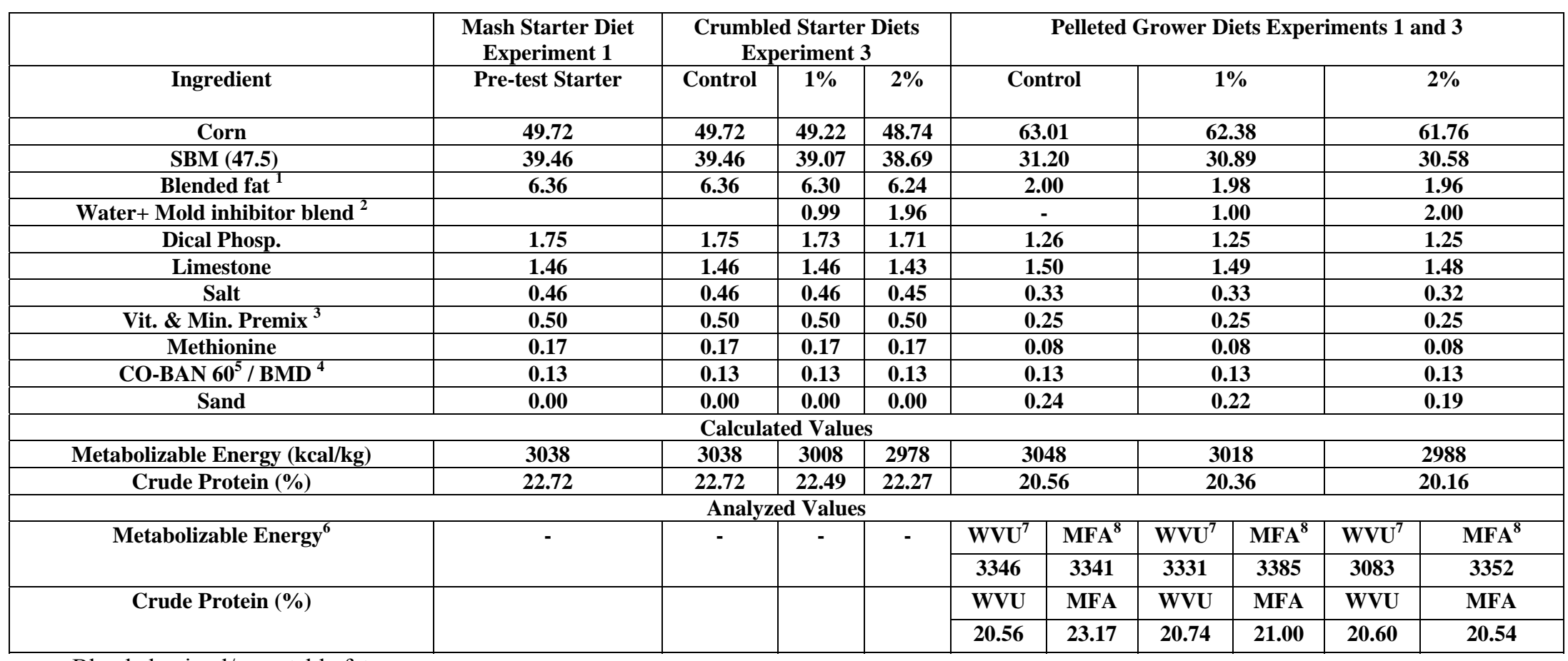

1 Blended animal/ vegetable fat source

2 Mixed at 95:5 ratio (water: mold inhibitor). Mold inhibitor contained propionic acid (30\%), butyric acid (30\%), aqueous ammonia solution (40\%)

3 Supplied per kilogram of diet: manganese, $0.02 \%$; zinc, $0.02 \%$; iron, $0.01 \%$; copper, $0.0025 \%$; iodine, $0.0003 \%$; selenium, $0.00003 \%$; folic acid, 0.69 $\mathrm{mg}$; choline, $386 \mathrm{mg}$; riboflavin, $6.61 \mathrm{mg}$; biotin, $0.03 \mathrm{mg}$; vitamin B6, $1.38 \mathrm{mg}$; niacin, 27.56mg; pantothenic acid, $6.61 \mathrm{mg}$; thiamine, $2.20 \mathrm{mg}$; menadione, $0.83 \mathrm{mg}$; vitamin B12, $0.01 \mathrm{mg}$; vitamin E, $16.53 \mathrm{IU}$; vitamin D3, 2,133 ICU; vitamin A, 7,716 IU.

43 Bacitracin methylene disalicylate, $50 \mathrm{~g} / \mathrm{lb}(50 \mathrm{~g} /$ ton inclusion) to increase weight gain and improve feed efficiency; Alpharma,Fort Lee, NJ.

5 Active drug ingredient is monensin sodium, $60 \mathrm{~g} / \mathrm{lb}(90 \mathrm{~g} /$ ton inclusion) as an aid in the prevention of coccidiosis caused_by Eimeria necatrix, Eimeria tenella, Eimeria acervulina, Eimeria brunette, Eimeria mivati, and Eimeria maxima; Elanco_Animal Health, Indianapolis, IN.

$6 \quad$ ME determined with Single Comb White Leghorn Roosters (Experiment 4)

7 Diets manufactured at West Virginia University Pilot feed mill. Morgantown, WV

8 Diets manufactured at MFA Inc. Lebannon, MO 
Table 2: Feed Manufacture Variables (Experiment 1)

\begin{tabular}{|c|c|c|c|c|c|c|c|c|c|c|c|}
\hline Treatment & $\begin{array}{c}\% \\
\text { Moistur } \\
\text { e (day 1) } \\
\pm \\
\text { SD }\end{array}$ & $\begin{array}{c}\% \\
\text { Moisture } \\
\text { (day 2) } \\
\pm \\
\text { SD }\end{array}$ & $\begin{array}{c}\% \\
\text { Moisture } \\
\text { (day 3) } \\
\pm \\
\text { SD }\end{array}$ & $\begin{array}{c}\text { Production } \\
\text { rate } \\
\text { (Mton/hr) } \\
\pm \\
\text { SD }\end{array}$ & $\begin{array}{c}\mathrm{BD}^{1} \\
(\%) \\
\pm \\
\mathrm{SD}\end{array}$ & $\begin{array}{c}\mathrm{BF}^{2} \\
(\%) \\
\pm \\
\mathrm{SD}\end{array}$ & $\begin{array}{c}\mathrm{CF}^{3} \\
(\%) \\
\pm \\
\mathrm{SD}\end{array}$ & $\begin{array}{c}\mathrm{TF}^{4} \\
(\%) \\
\pm \\
\mathrm{SD}\end{array}$ & $\begin{array}{c}\mathrm{PDI}^{5} \\
(\%) \\
\pm \\
\mathrm{SD}\end{array}$ & $\begin{array}{c}\mathrm{MPDI}^{6} \\
(\%) \\
\pm \\
\mathrm{SD}\end{array}$ & $\begin{array}{c}\mathrm{REE}^{7} \\
(\mathrm{kwh} / \mathrm{Mton})\end{array}$ \\
\hline Control & $\begin{array}{c}13.66^{\mathrm{C}} \\
\pm \\
0.51\end{array}$ & $\begin{array}{c}11.98 \\
\pm \\
0.27 \\
\end{array}$ & $\begin{array}{c}11.09 \\
\pm \\
0.73 \\
\end{array}$ & $\begin{array}{c}1.38 \\
\pm \\
0.08 \\
\end{array}$ & $\begin{array}{c}39.81 \\
\pm \\
0.51 \\
\end{array}$ & $\begin{array}{l}9.20 \\
\pm \\
0.70 \\
\end{array}$ & $\begin{array}{c}50.62 \\
\pm \\
10.44 \\
\end{array}$ & $\begin{array}{c}13.10 \\
\pm \\
0.83 \\
\end{array}$ & $\begin{array}{c}89.54 \\
\pm \\
0.89 \\
\end{array}$ & $\begin{array}{c}81.96 \\
\pm \\
2.79 \\
\end{array}$ & 4.42 \\
\hline $\begin{array}{c}1 \% \\
\text { moisture/mol } \\
\mathrm{d} \text { inhibitor } \\
\end{array}$ & $\begin{array}{c}14.17^{\mathbf{b}} \\
\pm \\
0.39 \\
\end{array}$ & $\begin{array}{c}12.48 \\
\pm \\
0.40 \\
\end{array}$ & $\begin{array}{c}11.09 \\
\pm \\
1.00\end{array}$ & $\begin{array}{c}1.34 \\
\pm \\
0.04\end{array}$ & $\begin{array}{c}39.73 \\
\pm \\
0.78\end{array}$ & $\begin{array}{c}10.80 \\
\pm \\
1.57\end{array}$ & $\begin{array}{c}54.31 \\
\pm \\
2.80\end{array}$ & $\begin{array}{c}14.91 \\
\pm \\
1.48\end{array}$ & $\begin{array}{c}89.87 \\
\pm \\
1.74\end{array}$ & $\begin{array}{l}82.68 \\
\pm \\
3.27\end{array}$ & 4.16 \\
\hline $\begin{array}{c}2 \% \\
\text { moisture/mol } \\
\mathrm{d} \text { inhibitor } \\
\end{array}$ & $\begin{array}{c}15.04^{\mathbf{a}} \\
\pm \\
0.32 \\
\end{array}$ & $\begin{array}{c}12.88 \\
\pm \\
0.70 \\
\end{array}$ & $\begin{array}{c}11.68 \\
\pm \\
0.60 \\
\end{array}$ & $\begin{array}{c}1.32 \\
\pm \\
0.06 \\
\end{array}$ & $\begin{array}{c}39.45 \\
\pm \\
0.23 \\
\end{array}$ & $\begin{array}{c}10.18 \\
\pm \\
1.81 \\
\end{array}$ & $\begin{array}{c}54.53 \\
\pm \\
4.29 \\
\end{array}$ & $\begin{array}{c}13.03 \\
\pm \\
1.29 \\
\end{array}$ & $\begin{array}{c}90.31 \\
\pm \\
0.99 \\
\end{array}$ & $\begin{array}{c}83.44 \\
\pm \\
2.78 \\
\end{array}$ & 3.87 \\
\hline \multicolumn{12}{|c|}{ P-Values } \\
\hline ANOVA & 0.0017 & 0.2917 & 0.3078 & .2686 & 0.2227 & 0.7172 & 0.4546 & 0.3147 & 0.5948 & 0.1993 & - \\
\hline $\mathrm{LSD}^{8}$ & 0.1696 & - & - & - & - & - & - & - & - & - & - \\
\hline Linear & 0.0036 & 0.0462 & 0.3717 & 0.2602 & 0.4147 & 0.4406 & 0.4712 & 0.9542 & 0.4461 & 0.5287 & - \\
\hline Quadratic & 0.0029 & 0.0522 & 0.3352 & 0.2787 & 0.3978 & 0.5399 & 0.5105 & 0.7670 & 0.4447 & 0.5321 & - \\
\hline
\end{tabular}

a,b,c- different superscripts denote differences within columns

$\mathrm{BD}=$ bulk density

$\mathrm{BF}=$ bagged fines $-\%$ fines estimated in a $50 \mathrm{lb}$ bag of sacked off pellets

$\mathrm{CF}=$ cooler fines $-\%$ fines collected under the horizontal cooler during manufacture

$\mathrm{TF}=$ total fines - estimation of total fines, calculated from $\mathrm{BF}$ and $\mathrm{CF}$ percentages

$\mathrm{PDI}=$ pellet durability index

MPDI $=$ modified pellet durability index

$\mathrm{REE}=$ relative electrical energy usage - presented as descriptive data due to lack of replication.

$8 \mathrm{LSD}=$ Fisher's least significant difference 
Table 3: 21-42d broiler performance variables (Experiment 2)

\begin{tabular}{|c|c|c|c|c|c|}
\hline Treatment & $\begin{array}{c}\mathrm{LWG}^{1}(\mathrm{~kg}) \\
\pm \\
\mathrm{SD}\end{array}$ & $\begin{array}{c}\mathrm{FI}^{2}(\mathrm{~kg}) \\
\pm \\
\mathrm{SD}\end{array}$ & $\begin{array}{c}\text { Mortality (\%) } \\
\pm \\
\text { SD }\end{array}$ & $\begin{array}{c}\mathrm{FC}^{3}(\mathrm{~kg} / \mathrm{kg}) \pm \\
\mathrm{SD}\end{array}$ & $\begin{array}{c}\mathrm{BW}^{4}(\mathrm{~kg}) \\
\pm \\
\mathrm{SD}\end{array}$ \\
\hline Control & $\begin{array}{c}1.60 \\
\pm \\
0.16\end{array}$ & $\begin{array}{c}51.57 \\
\pm \\
2.87\end{array}$ & $\begin{array}{l}8.02 \\
\pm \\
8.85\end{array}$ & $\begin{array}{c}1.98 \\
\pm \\
0.21\end{array}$ & $\begin{array}{c}2.38 \\
\pm \\
0.16\end{array}$ \\
\hline $\begin{array}{l}\text { 1\% moisture/mold } \\
\text { inhibitor }\end{array}$ & $\begin{array}{c}1.60 \\
\pm \\
0.08\end{array}$ & $\begin{array}{c}49.26 \\
\pm \\
5.05\end{array}$ & $\begin{array}{c}4.86 \\
\pm \\
5.83\end{array}$ & $\begin{array}{c}1.93 \\
\pm \\
0.21\end{array}$ & $\begin{array}{c}2.36 \\
\pm \\
0.07\end{array}$ \\
\hline $\begin{array}{l}2 \% \text { moisture } / \text { mold } \\
\text { inhibitor }\end{array}$ & $\begin{array}{c}1.50 \\
\pm \\
0.09\end{array}$ & $\begin{array}{c}49.88 \\
\pm \\
5.28\end{array}$ & $\begin{array}{c}10.40 \\
\pm \\
10.48\end{array}$ & $\begin{array}{c}2.06 \\
\pm \\
0.17\end{array}$ & $\begin{array}{c}2.30 \\
\pm \\
0.06\end{array}$ \\
\hline \multicolumn{6}{|c|}{ P-Values } \\
\hline ANOVA & 0.1378 & 0.3945 & 0.3757 & 0.3900 & 0.2797 \\
\hline Linear & 0.0667 & 0.3175 & 0.5461 & 0.3410 & 0.0983 \\
\hline Quadratic & 0.0362 & 0.4967 & 0.3482 & 0.2029 & 0.0834 \\
\hline \multicolumn{6}{|c|}{$\begin{array}{ll}1 & \mathrm{LWG}=\text { live wt. gain per bird } \\
2 & \mathrm{FI}=\text { feed intake per pen } \\
3 & \mathrm{FC}=\text { feed conversion ratio (feed:gain) } \\
4 & \mathrm{BW}=42 \text { day body weight }\end{array}$} \\
\hline
\end{tabular}


Table 4: Broiler Performance (Experiment 3)

\begin{tabular}{|c|c|c|c|c|c|c|c|c|c|c|c|}
\hline & \multicolumn{3}{|c|}{ Milling Data } & \multicolumn{4}{|c|}{ 0-21d Broiler Performance } & \multicolumn{4}{|c|}{ 21-42d Broiler Performance } \\
\hline Trt & $\mathrm{PDI}^{1}$ & $\mathrm{MPDI}^{2}$ & Moisture \% & $\begin{array}{c}\mathrm{LWG}^{3}(\mathrm{~kg}) \\
\pm \\
\mathrm{SD}\end{array}$ & $\begin{array}{c}\text { FI (kg) } \\
\pm \\
\text { SD }\end{array}$ & $\begin{array}{c}\mathrm{FC}^{5} \\
\pm \\
\mathrm{SD}\end{array}$ & $\begin{array}{c}\mathrm{BW}^{6}(\mathrm{~kg}) \\
\pm \\
\mathrm{SD}\end{array}$ & $\begin{array}{c}\mathrm{LWG}^{3}(\mathrm{~kg}) \\
\pm \\
\mathrm{SD}\end{array}$ & $\begin{array}{c}\mathrm{FI}^{4}(\mathrm{~kg})^{2} \\
\pm \\
\mathrm{SD}\end{array}$ & $\begin{array}{c}\mathrm{FC}^{5} \\
\pm \\
\mathrm{SD}\end{array}$ & $\begin{array}{c}\mathrm{BW}^{6}(\mathrm{~kg}) \\
\pm \\
\mathrm{SD}\end{array}$ \\
\hline Control & 93.39 & 87.13 & 11.66 & $\begin{array}{c}0.70^{\mathbf{c}} \\
\pm \\
0.02\end{array}$ & $\begin{array}{c}1.09^{\mathbf{b}} \\
\pm \\
0.05\end{array}$ & $\begin{array}{c}1.54 \\
\pm \\
0.06\end{array}$ & $\begin{array}{c}0.74^{\mathrm{c}} \\
\pm \\
0.02\end{array}$ & $\begin{array}{c}1.75^{\mathrm{b}} \\
\pm \\
0.07\end{array}$ & $\begin{array}{c}3.67 \\
\pm \\
0.26\end{array}$ & $\begin{array}{c}2.05^{\mathrm{a}} \\
\pm \\
0.12\end{array}$ & $\begin{array}{c}2.55^{\mathbf{b}} \\
\pm \\
0.08\end{array}$ \\
\hline $1 \%$ & 96.59 & 92.17 & 11.53 & $\begin{array}{c}0.7625^{\mathrm{a}} \\
\pm \\
0.02\end{array}$ & $\begin{array}{c}1.25^{\mathrm{a}} \\
\pm \\
0.11\end{array}$ & $\begin{array}{c}1.63 \\
\pm \\
0.13\end{array}$ & $\begin{array}{c}0.81^{\mathrm{a}} \\
\pm \\
0.02\end{array}$ & $\begin{array}{c}1.74^{\mathbf{b}} \\
\pm \\
0.08\end{array}$ & $\begin{array}{c}3.75 \\
\pm \\
0.26\end{array}$ & $\begin{array}{c}1.95^{\mathbf{b}} \\
\pm \\
0.05\end{array}$ & $\begin{array}{c}2.57^{\mathbf{b}} \\
\pm \\
0.06\end{array}$ \\
\hline $2 \%$ & 95.53 & 90.89 & 12.65 & $\begin{array}{c}0.7300^{\mathbf{b}} \\
\pm \\
0.03\end{array}$ & $\begin{array}{c}1.18^{\mathbf{a b}} \\
\pm \\
0.16\end{array}$ & $\begin{array}{c}1.61 \\
\pm \\
0.18\end{array}$ & $\begin{array}{c}0.77^{\mathbf{b}} \\
\pm \\
0.03\end{array}$ & $\begin{array}{c}1.82^{\mathrm{a}} \\
\pm \\
0.07\end{array}$ & $\begin{array}{c}3.85 \\
\pm \\
0.27\end{array}$ & $\begin{array}{c}2.05^{\mathrm{a}} \pm \\
0.11\end{array}$ & $\begin{array}{c}2.65^{\mathrm{a}} \\
\pm \\
0.07\end{array}$ \\
\hline ANOVA & - & - & - & .0001 & .0054 & .2233 & .0001 & 0131 & .1828 & .0202 & .0007 \\
\hline $\mathrm{LSD}^{7}$ & - & - & - & 0.0181 & 0.0957 & - & 0.0182 & 0.0564 & - & 0.0787 & 0.0519 \\
\hline
\end{tabular}

a,b,c Different superscripts indicate differences within columns

$\mathrm{PDI}=$ pellet durability index (descriptive data)

MPDI=modified pellet durability index (descriptive data)

$\mathrm{LWG}=$ live wt. gain per bird

$\mathrm{FI}=$ feed intake per pen

$\mathrm{FC}=$ feed conversion ratio (feed:gain)

$\mathrm{BW}=$ ending body weight

$\mathrm{LSD}=$ Fisher's least significant difference 
Table 5: Nitrogen Corrected True Metabolizable Energy (Experiment 4)

\begin{tabular}{|c|c|}
\hline TRT & TMEn (kcal/kg) \\
& \pm \\
& SD \\
\hline WVU $^{1}$ Control & 3347 \\
& \pm \\
& 216 \\
\hline WVU 1\% & 3332 \\
& \pm \\
& 231 \\
\hline WVU 2\% & 3083 \\
& \pm \\
& 114 \\
\hline MFA ${ }^{2}$ Control & 3342 \\
& \pm \\
& 195 \\
\hline MFA 1\% & 3386 \\
& \pm \\
\hline MFA 2\% & 91 \\
& \pm \\
& 152 \\
\hline ANOVA & 0.1743 \\
\hline Moisture & 0.1956 \\
\hline Mill & 0.1314 \\
\hline Moisture * Mill & 0.2406 \\
\hline & \\
\hline
\end{tabular}

1. West Virginia University Pilot Feed Mill, Morgantown, WV 2. MFA Incorporated, Lebannon, MO 
Appendix I: Composition and properties of mold inhibitor.

\begin{tabular}{|c|c|}
\hline \multicolumn{2}{|c|}{ Composition } \\
\hline Propionic Acid & $30 \%$ \\
\hline Butyric Acid & $30 \%$ \\
\hline $\begin{array}{c}\text { Aqueous Ammonia } \\
\text { Solution } \\
\text { (Buffering Agent) }\end{array}$ & $40 \%$ \\
\hline
\end{tabular}

\begin{tabular}{|c|c|}
\hline \multicolumn{2}{|c|}{ Properties } \\
\hline $\mathrm{pH}$ & $6.9-7.1$ \\
\hline Boiling Point & $101.6^{\circ} \mathrm{C}$ \\
\hline Specific Gravity & 1.047 at $20^{\circ} \mathrm{C}$ \\
\hline Flash Point & $85^{\circ} \mathrm{C}$ \\
\hline Stability & $>2 \mathrm{yrs}$ \\
\hline
\end{tabular}

